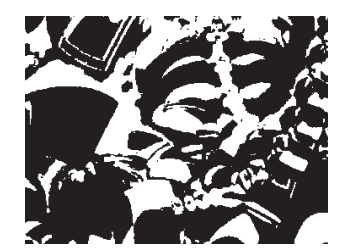

\title{
ATTITUDES TOWARDS CITIZEN PARTICIPATION IN THE LOCAL DECISION-MAKING PROCESS: A COMPARATIVE ANALYSIS
}

Dubravka JURLINA ALIBEGOVIĆ, Sunčana SLIJEPČEVIĆ

The Institute of Economics, Zagreb

UDK: $351.075 .1(4)$

$316.644(4): 352$

Izvorni znanstveni rad

Primljeno: 28. 8. 2015.

A very important pillar of democracy is the involvement of citizens in the political decision-making process. The change from "government" to "governance", which has been also noticed in the literature, implies a greater involvement of different stakeholders in the decision-making process and in the process of public policy implementation. Citizens' participation in the process of public services delivery may lead to better public services, which comply with the needs of citizens, better decisions, higher quality and more efficient collaboration in using public money for public services. This research empirically tests attitudes towards greater citizens' involvement in the decision-making process at the local level. We compare attitudes of local councillors in 16 countries divided according to the expanded Hesse-Sharpe (1991) typology. The analysis is based on the result of a survey conducted among local city councillors. We examine different mechanisms of citizen participation in the decision-making process from the comparative perspective. Our research showed voting to be the most preferable mechanism for public participation in all groups of countries, while citizens' juries are the least preferable mechanism for citizen participation. This research contributes to filling the research gap concerning the role and the importance of citizens' participation in the decision-making process in Europe.

Keywords: citizen participation, local councillors, local public services, local development

Dubravka Jurlina Alibegović, The Institute of Economics, Trg J. F. Kennedyja 7, 10000 Zagreb, Croatia. E-mail: djurlina@eizg.hr 
This research empirically analyses public participation in the decision-making process from the local councillors' perspective. According to the European Institute for Public Participation (2009), public participation can be described as a deliberative process by which interested or affected citizens, civil society organizations and government actors are involved in policy-making before a political decision is taken. There are many other definitions, mostly related to the involvement of citizens in political decision-making through different modes of participation (Chi, Xu \& Xue, 2014). Participation has a number of positive effects, including the adoption of advanced decisions, increased partnership, ownership and responsibility in the implementation of decisions, as well as increased confidence in public institutions (Hartay, 2011). Literature stresses that citizens' participation in the decision-making process is an important pillar of democracy (European Institute for Public Participation, 2009; Michels \& De Graaf, 2010; Tanaka, 2007; OECD, 2001), but also emphasises that a citizen's trust and interest in politicians and political institutions has declined in a number of countries (Rosenberg, 2007; Roberts, 2004). As noticed by Rosenberg (2007), people mostly have the opinion that politics does not reflect the needs of the public at large.

Therefore, we analyse attitudes towards larger public participation in the decision-making process at the local level. To analyse this, we examine whether the local councillors find it important for the residents to have an opportunity to express their opinions and thus influence local policy. Heinelt (2013) showed that many councillors in Europe have a positive attitude towards participation in local democracy. England is an excellent example of the regulation and the implementation of consultation processes and other participatory tools at the local level (Hartay, 2011). In this research, we analyse the differences between groups of countries with different vertical power relations between the central and local political system. Also, we analyse what local councillors' attitudes are towards different modes of public participation in the decision-making process in cities. We compare the attitudes of local councillors in 16 countries divided according to the expanded Hesse-Sharpe (1991) typology in Anglo, Franco, North and Middle European and Central East European countries (including Israel).

This research consists of four parts. After the introduction, in the second part, the literature review dealing with different modes of citizens' participation is presented. Methodology, sample and results of the survey among local councillors are presented in the third part. The final part summarises the main conclusion. 


\section{MODES OF PUBLIC PARTICIPATION \\ IN THE DECISION-MAKING PROCESS}

Citizen participation can be seen as a process in which citizens organise themselves and their goals at the grassroots level and work together through non-governmental community organisations to influence the decision-making process (Gilbreath Holdar \& Zakharchenko, 2002). The importance of citizens' participation in decision-making at the local level is stated in the Council of Europe (2011a) Resolution 326. The Resolution stresses that there is a growing need for the citizens in the European countries to be included by their elected representatives and to be able, also between elections, to influence politics at all levels. Citizens' right to elect public officials is only one form of citizen participation (Forrester \& Sunar, 2011). Citizen participation enables citizens to set goals and priorities, oversee actions of politicians and members of the state administration and hold them responsible for their actions, express their views, requirements and problems, monitor and evaluate results of policy implementation, and other actions (Kelly \& Swindell, 2002; Lowndes, Pratchett \& Stoker, 2001). The participatory approach to public policy can encourage a shift from "government" to "governance", involvement of a range of stakeholders in public policy development and implementation. This shift indicates the idea of democratic administration explained by Wamsley \& Wolf (1996). As stressed by Heinelt, (2013, p. 85) "municipal councils are representative bodies and are thus a core institution of a particular understanding of democracy - namely representative or liberal democracy". The literature on political theory is relatively wide and beyond the scope of this research, so more on the literature that contributes to the understanding of democracy in the EU countries could be found in Egner, Sweeting, \& Klok (2013), Bertrana, Egner \& Heinelt (2016), Abelson et al. (2003), Quick \& Bryson (2016), European Institute for Public Participation (2009), Renn, Webler, Rakel, Dienel, \& Johnson (1993).

The literature furthermore recognises the dilemma regarding the type and the mode of citizen participation in the governance at the local level (Rosenberg, 2007; Wilson, 1999; Thomas, 1995; Day, 1997; Hartay, 2011) and suggests that there are different advantages and disadvantages of citizen participation in the government decision-making process both for the citizen and the government (summarised in Table 1).

Citizen participation can be seen in various forms that vary from passive participation including information sharing, consultation through public hearing and open-houses, interactive participation through workshops and partnership arrangement to active participation (Chi et al., 2014). Passive participation has many disadvantages because it spends resources and time, as opposed to active participation which brings citizens' 
DRUŠ. ISTRAŽ. ZAGREB GOD. 27 (2018), BR. 1, STR. $155-175$

JURLINA ALIBEGOVIĆ, D. SLIJEPČEVIĆ, S.:

ATTITUDES TOWARDS..

(1) TABLE

Summary of advantages and disadvantages of citizen participation in decision-making positive attitudes regarding many topics of public interest. Countries have different experience in citizen participation. In some countries the right of participation is regulated by as high as the Constitution (e.g. in Hungary and Croatia). Certain aspects of citizen participation are regulated by local self-government law. England and Austria are countries characterised by the involvement of all stakeholders in the decision-making process (Hartay, 2011). On the local level, England demonstrates a good practice for both the regulation and the implementation of consultation processes and other participatory tools. In Central and South-Eastern European countries, however, many local governments still do not have institutional frameworks and capacity for participatory processes.

\begin{tabular}{|c|c|c|c|c|}
\hline & \multicolumn{2}{|l|}{ Advantages } & \multicolumn{2}{|l|}{$\underline{\text { Disadvantages }}$} \\
\hline & Citizens & Government & Citizens & Government \\
\hline $\begin{array}{l}\text { Decision-making } \\
\text { process }\end{array}$ & $\begin{array}{l}\text { Education (learn } \\
\text { from and inform } \\
\text { government } \\
\text { representatives); } \\
\text { Persuade and } \\
\text { enlighten go- } \\
\text { vernment; Gain } \\
\text { skills for activist } \\
\text { citizenship }\end{array}$ & $\begin{array}{l}\text { Education (learn } \\
\text { from and inform } \\
\text { citizens); Persuade } \\
\text { citizens, build trust } \\
\text { and allay anxiety } \\
\text { or hostility; Build } \\
\text { strategic alliances; } \\
\text { Gain legitimacy } \\
\text { of decisions }\end{array}$ & $\begin{array}{l}\text { Time consum- } \\
\text { ing; Pointless if } \\
\text { the decision is } \\
\text { ignored }\end{array}$ & $\begin{array}{l}\text { Time consum- } \\
\text { ing; Costly; } \\
\text { May backfire, } \\
\text { creating more } \\
\text { hostility to- } \\
\text { wards the } \\
\text { government }\end{array}$ \\
\hline Outcomes & $\begin{array}{l}\text { Break gridlock, } \\
\text { achieve outcomes; } \\
\text { Gain some con- } \\
\text { trol over policy } \\
\text { process; Better } \\
\text { policy and im- } \\
\text { plementation } \\
\text { decisions }\end{array}$ & $\begin{array}{l}\text { Break gridlock, } \\
\text { achieve outcomes; } \\
\text { Avoid litigation } \\
\text { costs; Better policy } \\
\text { and implementaion } \\
\text { decisions }\end{array}$ & $\begin{array}{l}\text { Worse policy } \\
\text { decision if } \\
\text { heavily infulen- } \\
\text { ced by oppos- } \\
\text { ing interest } \\
\text { group }\end{array}$ & $\begin{array}{l}\text { Loss of } \\
\text { decision-mak- } \\
\text { ing control; } \\
\text { Possibility of } \\
\text { bad decision } \\
\text { that is political- } \\
\text { ly impossible } \\
\text { to ignore; } \\
\text { Less budget } \\
\text { for implemen- } \\
\text { tation of actual } \\
\text { projects }\end{array}$ \\
\hline
\end{tabular}

Source: Irvin \& Stansbury (2004).

According to the Council of Europe (2011b), in several countries (e.g. France, Ireland) procedures of direct democracy are not so well-accepted in local decision-making. On the contrary, some Central and Eastern European countries (e.g. Croatia) show that local participation is stronger in cities than in rural areas due to the lack of human and financial capacity for the activities directed towards local and regional government (Pavić-Rogošić, 2012). In Hungary, Greece, Latvia, Serbia, Slovenia and Ukraine, public hearings are the most ubiquitous form of citizen participation (Soos, 2003). 
DRUŠ. ISTRAŽ. ZAGREB GOD. 27 (2018), BR. 1 STR. $155-175$

JURLINA ALIBEGOVIĆ, D. SLIJEPČEVIĆ, S.:

ATTITUDES TOWARDS...
Citizens can participate in local governance by expressing their own needs and by participating in local project planning (Day, 1997) and/or budget planning and monitoring (Ebdon, 2002; Tanaka, 2007). The participatory budgeting method is one of the methods which involve citizens in the financial planning of the city, participating in local budget planning, and capital investment plan. The Council of Europe (2011b, p. 22) report states "there is also an increasing interest in participatory budgeting in Europe which directly involves local people in making decisions on the spending and priorities for a defined public budget. When it works well, it can improve transparency in public spending and even boost revenues. It is widely considered to be a tool for making cities more inclusive and mobilising passive citizens. There is no single model, as the practice represents a range of initiatives with their own characteristics. France, Germany, Spain and the United Kingdom all have cities and regions which have used this tool."

There are several modes of public participation in the decision-making process. Based on Gilbreath Holdar and Zakharchenko (2002) and Callahan (2007), important forms of citizen participation include public hearings, public meetings, campaigns, civil associations, citizen advisory committees and petitions. According to the Council of Europe (2011b), popular assembly is the strongest form of direct democracy. It can provide an opportunity for the whole local community to discuss and decide on local public matters. Citizens' meetings and public hearings are more widespread than popular assemblies. These instruments of direct contact between local authority and local population provide a forum for citizens to express their views, wishes or proposals. This form of citizen participation in general is recognised in Austria, Croatia, Estonia, Greece, Hungary, Malta, Romania, Serbia, Slovenia, Spain, Macedonia, Turkey and Ukraine. The role of citizens' meetings and public hearings is purely consultative in local policy-making. In Ireland and the United Kingdom consultative mechanisms are maintained in land use planning and public transport. In Italy, local citizens may set up a "citizens' monitoring board" in order to supervise their municipality's "strategic plan". There are alternative forms of citizen participation. For example, "public debates" or "citizens' meetings". One which is found in various countries is the possibility of establishing "neighbourhood councils". In the Netherlands these councils try to improve all kinds of aspects of living conditions in their villages or neighbourhoods. They also serve as discussion partners for the municipal council.

Public participation in decision-making related to local affairs should be observed in relation to sub-national government responsibilities. In the analysed countries, sub-national government has different responsibilities, as well as the finan- 
DRUŠ. ISTRAŽ. ZAGREB GOD. 27 (2018), BR. 1, STR. $155-175$

JURLINA ALIBEGOVIĆ, D. SLIJEPČEVIĆ, S.: ATTITUDES TOWARDS..

(1) TABLE 2

Distribution of powers and responsibilities on local economic development cial powers for financing those responsibilities. Decentralisation reforms have been, with a different pace, approaches and success, conducted in almost all European countries during the last forty years (Ismeri Europa \& Applica, 2010). In all countries great attention is focused on improving the efficiency of public spending while increasing the quality of public services (Skelcher, 1992; Eyben \& Ladbury, 2006; Petts, 2001; Robinson, 2007). Some countries have a positive experience in the engagement of citizens in budgeting, planning and urban development (Tanaka, 2007; European Institute for Public Participation, 2009).

In most countries, the distribution of powers and responsibilities on local economic development or otherwise stated administrative decentralisation has not been followed by an adequate level of fiscal decentralisation (Table 2). Moreover, responsibility transferred to local authorities for the provision of public services is not fully in compliance with the existing level of fiscal autonomy of sub-national government units (Table 3). Recent experiences indicate that countries with more independent local governments, in other words, countries with a higher degree of local and political autonomy have a positive attitude toward citizen participation in decision-making (Box, 1998; Ebdon, 2002). Razin \& Hazan (2014) show that there is a difference between Northern and Southern Europe regarding the attitudes of local councillors towards reforms and notions of democracy, participation and devolution of public functions. The degree of decentralisation in the country and the responsibility of local governments in providing public services to citizens affect the ability of citizens to directly participate in decision-making regarding local tasks through referendums and group meetings with citizens.

\begin{tabular}{lllll}
\hline & $\begin{array}{l}\text { Belgium, } \\
\text { Germany }\end{array}$ & $\begin{array}{l}\text { Spain, } \\
\text { Italy }\end{array}$ & $\begin{array}{l}\text { Sweden, } \\
\text { Norway }\end{array}$ & $\begin{array}{l}\text { Other } \\
\text { countries }\end{array}$ \\
\hline Infrastructure and services & ++ & +++ & +++ & ++ \\
Transport and communications & ++ & ++ & + & ++ \\
Energy & + & + & ++ & + \\
Environment & +++ & +++ & +++ & +++ \\
Health & ++ & + & + & + \\
Housing & ++ & +++ & +++ & + \\
Public safety & ++ & ++ & & + \\
Culture & +++ & ++ & +++ & +++ \\
Social services & +++ & +++ & +++ & + \\
Education and training & + & + & ++ & ++ \\
Aid schemes for development & +++ & & & \\
\hline
\end{tabular}

Note: +++ high importance; ++ medium importance; + low importance; blank $=$ no importance. Source: Systematisation based on Ismeri Europa \& Applica (2010). 
DRUŠ. ISTRAŽ. ZAGREB GOD. 27 (2018), BR. 1 STR. $155-175$

JURLINA ALIBEGOVIĆ, D. SLIJEPČEVIĆ, S.: ATTITUDES TOWARDS...

(1) TABLE 3

Fiscal autonomy of sub-national government units
The process of citizen participation in local public services delivery is not a simple mission. Based on evidence provided by Ploštajner et al. (2001), experiences of South-Eastern European countries show insufficient cooperation among politicians, citizens and local administration to establish a legal framework in order to ensure participation in the policy-making process. In the past few years, some South-Eastern European countries (e.g. Croatia) have improved this situation by adopting the Code of Practice on Consultation with the Interested Public in Procedures of Adopting Laws, Other Regulations and Acts (Pavić-Rogošić, 2012). Citizen participation in decision-making at the local level can enhance the efficiency in the local public services provision based on the inclusion of citizens in the public service development and delivery process. In such a way, citizen participation may have an impact on better public services, quality assessment, and satisfaction with public service (Eyben \& Ladbury, 2006; LogoLink, 2004).

Share of own tax revenues

in total sub-national revenues

Countries

\begin{tabular}{lcl}
\hline High fiscal autonomy & Above $40 \%$ & Sweden, France \\
Medium high fiscal autonomy & $20-40 \%$ & $\begin{array}{l}\text { Italy, Belgium, Spain, Greece, } \\
\text { Hungary, Norway, Poland }\end{array}$ \\
Medium low fiscal autonomy & $10-20 \%$ & $\begin{array}{l}\text { Germany, United Kingdom, } \\
\text { Netherlands }\end{array}$ \\
Low fiscal autonomy & Below 10\% & Austria, Czech Republic, Croatia \\
\hline
\end{tabular}

Note: Systematisation into four levels of fiscal autonomy according to Ismeri Europa \& Applica (2010).

Source: Systematisation based on Eurostat.

\section{RESULTS OF THE SURVEY ON CITIZEN PARTICIPATION IN THE DECISION-MAKING PROCESS AT THE LOCAL LEVEL}

\section{Methodology and sample}

The empirical analysis is based on the MAELG (Municipal Assemblies in European Local Governance) survey data collected from local councillors from municipalities in 16 countries in the period until 2010. We analyse local councillors' attitudes in Germany, Switzerland, the Czech Republic, the Netherlands, Italy, Sweden, Norway, Poland, Austria, Greece, the United Kingdom, Belgium, France, Spain, Croatia and Israel. Within the scope of this project, an identical survey was sent to local councillors from municipalities which have more than 10,000 inhabitants. The English version of the questionnaire 
DRUŠ. ISTRAŽ. ZAGREB GOD. 27 (2018), BR. 1, STR. 155-175

JURLINA ALIBEGOVIĆ, D. SLIJEPČEVIĆ, S.: ATTITUDES TOWARDS.. was translated and contextualised by team members from all the countries involved in the MAELG project. Table 4 gives an overview of the survey coverage in the countries involved in the project. On average, the survey was sent to 23.4 percent of the total number of local councillors.

A total of 11,962 local councillors answered the questionnaire, which is a response rate of 23.1 percent (Figure 1). Regarding questionnaire items used in this analysis, the sample stayed almost the same. Almost 98.3 percent of councillors answered the questions analysed in this research.

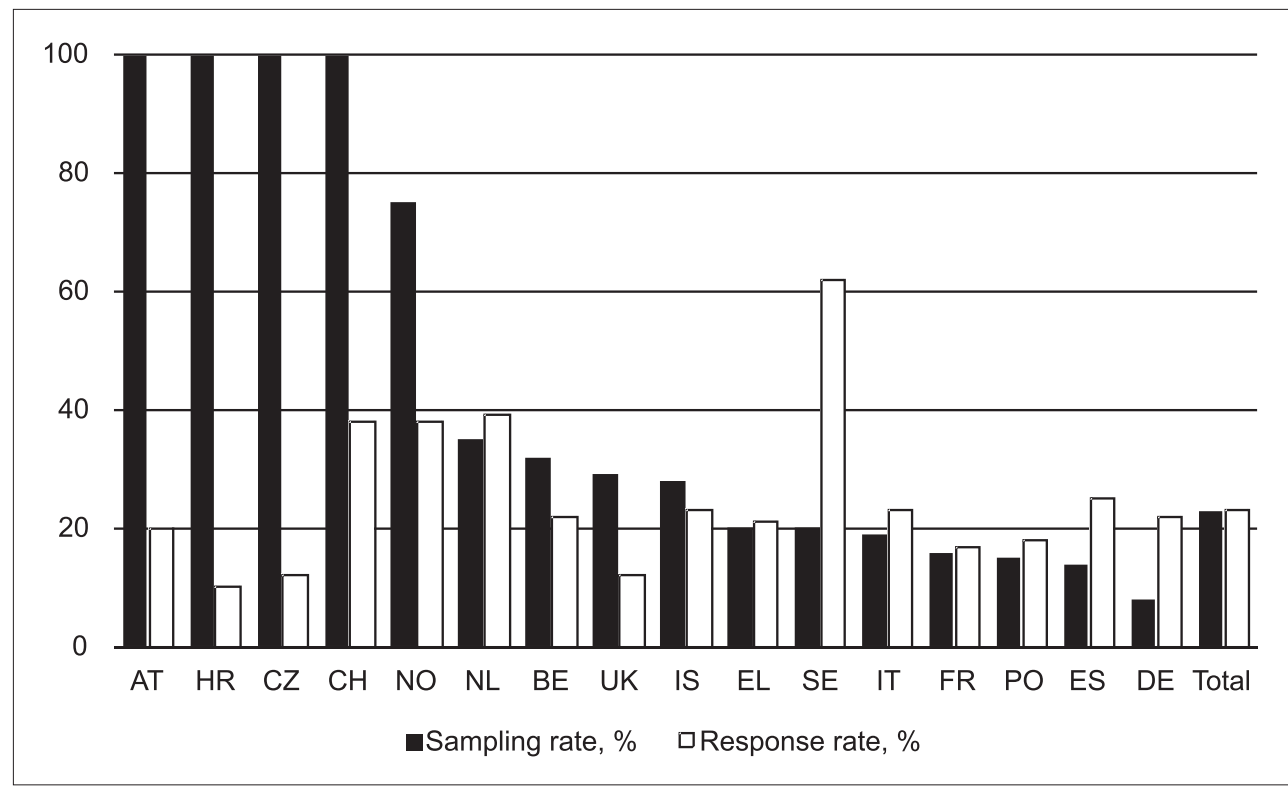

Source: Based on Egner, Sweeting, \& Klok (2013).

i) FIGURE 1

Sampling and response rate
These research results have been analysed using the expanded Hesse-Sharpe (1991) general classification of local governance according to which countries have been grouped into three groups according to their common characteristics: Franco, Anglo and Northern and Middle European countries. In addition, the MAELG database includes data from Central and Eastern European countries and Israel which were observed as an additional group consisting of Poland, the Czech Republic, Croatia and Israel. The sample by country group has been presented in Table 4.

In the research, we investigate local councillors' perceptions of public participation in the decision-making process. Each statement in the survey is analysed using a 5-point Likert scale. The existence of differences between groups of countries is tested using ANOVA analysis. 
P TABLE 4

Research sample by country groups,

$\mathrm{n}=11,752$

\begin{tabular}{lrr}
\hline & $\%$ & $\mathrm{~N}$ \\
\hline Franco & 27.5 & 3,239 \\
Anglo & 5.7 & 669 \\
Northern and Middle Europe & 55.6 & 6,534 \\
Central Eastern Europe + Israel & 11.2 & 1,310 \\
\hline
\end{tabular}

Note: Franco = Italy, Spain, Belgium, France, Greece; Anglo $=$ UK; Northern and Middle Europe = Germany, Switzerland, the Netherlands, Sweden, Norway, Austria; Central Eastern Europe + Israel = Poland, the Czech Republic, Croatia and Israel.

\section{Results}

(1) FIGURE 2

Local councillors' views about public participation in the analysed countries
Data from Figure 2 show the mean score of each of the analysed statements about local democracy in the analysed European countries and Israel. Results clearly show that the majority of local councillors from the analysed countries consider public participation not to be fundamental for local economic development. A proof of this is the average score of 2.75 (while the highest score is 5) on the statement that residents should participate actively and directly in making important local decisions.

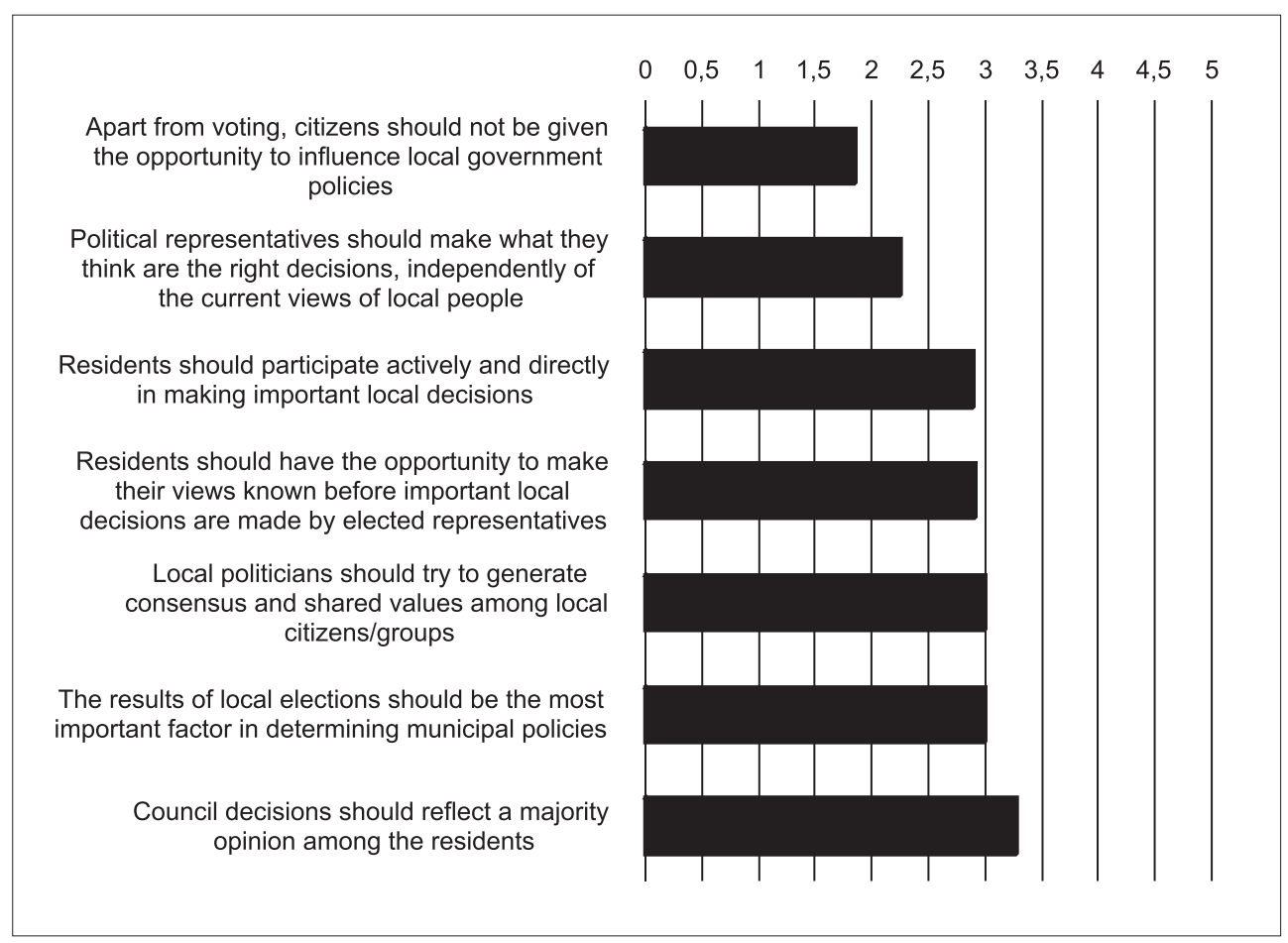

On the average, the local councillors' opinion is that the residents should have a chance to participate in decision-making by having an opportunity to make their views known before 
DRUŠ. ISTRAŽ. ZAGREB GOD. 27 (2018), BR. 1, STR. 155-175

JURLINA ALIBEGOVIĆ, D. SLIJEPČEVIĆ, S.: ATTITUDES TOWARDS..

(1) TABLE 5

Councillors attitudes toward stating citizens views before important local decisions (One-Way ANOVA) important local decisions are made by local elected representatives. They also consider that, apart from voting, citizens should be given other opportunities in the decision-making process to influence local government policies.

Our analysis shows the existence of a significant difference in councillors' attitudes regarding the question of whether residents should have an opportunity to state their views before important local decisions are made by elected representatives (Table 5). Most of the local councillors from the countries analysed strongly support that idea. More than 90 percent of the local councillors in the Anglo group rate this statement as being of great or utmost importance, while, in other groups of countries this share is lower at around 80 percent. The Anglo group gives this statement the highest mean score of 3.35. This is not surprising knowing that the United Kingdom has developed a very strong local democracy in order to involve all important stakeholders in the open local government (UK Open Government Network, 2017).

\begin{tabular}{|c|c|c|c|c|c|c|}
\hline Statement & $\begin{array}{l}\text { Franco } \\
M\end{array}$ & $\begin{array}{l}\text { Anglo, } \\
M\end{array}$ & $\begin{array}{l}\text { Northern } \\
\text { and Middle } \\
\text { Europe } \\
M\end{array}$ & $\begin{array}{l}\text { Central } \\
\text { Eastern } \\
\text { Europe } \\
M\end{array}$ & $d f$ & $F$ \\
\hline $\begin{array}{l}\text { Residents should have the opportunity } \\
\text { to make their views known before } \\
\text { important local decisions are made } \\
\text { by elected representatives }\end{array}$ & 3.04 & 3.35 & 3.08 & 3.07 & 3 & 29.537 \\
\hline $\begin{array}{l}\text { Political representatives should make } \\
\text { what they think are the right decisions, } \\
\text { independently of the current views } \\
\text { of local people }\end{array}$ & 2.19 & 2.49 & 1.94 & 2.41 & 3 & 109.323 \\
\hline $\begin{array}{l}\text { Residents should participate actively } \\
\text { and directly in making important } \\
\text { local decisions }\end{array}$ & 2.83 & 2.76 & 2.69 & 2.86 & 3 & 22.528 \\
\hline $\begin{array}{l}\text { Council decisions should reflect } \\
\text { a majority opinion among the residents }\end{array}$ & 2.73 & 2.36 & 2.78 & 3.01 & 3 & 77.569 \\
\hline $\begin{array}{l}\text { Results of local elections should be } \\
\text { the most important factor in deter- } \\
\text { mining municipal policies }\end{array}$ & 2.83 & 2.40 & 2.86 & 2.78 & 3 & 48.865 \\
\hline $\begin{array}{l}\text { Local politicians should try to generate } \\
\text { consensus and shared values among } \\
\text { local citizens/groups }\end{array}$ & 3.04 & 2.97 & 2.88 & 3.07 & 3 & 38.258 \\
\hline $\begin{array}{l}\text { Apart from voting, citizens should not } \\
\text { be given the opportunity to influence } \\
\text { local government policies }\end{array}$ & 1.40 & 1.31 & 1.16 & 1.52 & 3 & 57.477 \\
\hline
\end{tabular}

Note: All is significant at the $p=0.000$ level. 
DRUŠ. ISTRAŽ. ZAGREB GOD. 27 (2018), BR. 1 STR. 155-175

JURLINA ALIBEGOVIĆ, D. SLIJEPČEVIĆ, S.:

ATTITUDES TOWARDS...
In comparison with the Anglo group, the Northern and Middle European group (Germany, Switzerland, the Netherlands, Sweden, Norway, Austria) has a lower mean score (3.08), while the Franco group (Italy, Spain, Belgium, France, Greece) has the lowest mean score (3.04). Some countries have been working on the improvement of citizen participation in the political decision-making process. For example, the Netherlands modified the Municipalities Act in order to improve the good relationship between central and local authorities and citizens. The results are understandable when we know that, for example, the French Constitution establishes a local referendum on draft laws and other issues in its jurisdiction. In addition, the consequences of local government reforms in the 1990s strengthened citizen participation at the local level. This is accomplished by the law guaranteeing the right of access to information of local authorities, various forms of citizen consultations (local referendum, opinion polls, local self-government institutions, and advisory services of the local public services) and the right to petition (Lopižić, 2015).

The shares of respondents who agree with the opinion that residents should have an opportunity to state their views before important local decisions are made by the elected representatives oscillate between 67 percent in Switzerland and 93 percent in Norway and Greece. Despite that, a large share of local councillors in Greece also consider that political representatives should make what they think are the right decisions, independently of the current views of local people. In addition to Greece, more local councillors agree than disagree with that statement in the Czech Republic, Italy, Sweden, Croatia, Norway, Poland, the United Kingdom, Belgium, France and Israel.

Over 50 percent of the local councillors from Anglo and Central Eastern European countries find that it is of great or utmost importance that political representatives act independently of local citizens' views. The explanation for such a perception of the Anglo group definitely has a starting point in the belief that the majority decisions of local interests should be included into laws. This share is the lowest in Northern and Middle European countries, where there are more local councillors who consider that this is unimportant than those who consider it to be important. The Northern and Middle European group consists of countries with different experiences in political democracy and different level of public trust in politicians and transparency. The possibility of acting independently of citizens' preferences is no such problem in countries with a high degree of trust in local politicians. In countries with a low level of trust, it is necessary to give additional attention to and analyse the reasons for such distrust of citizens in local politicians, but also to explore why councillors find that it is ac- 
DRUŠ. ISTRAŽ. ZAGREB GOD. 27 (2018), BR. 1, STR. 155-175

JURLINA ALIBEGOVIĆ, D. SLIJEPČEVIĆ, S.: ATTITUDES TOWARDS. ceptable to make independent decisions, regardless of the low level of citizens' trust in their decisions.

Over 50 percent of respondents find that residents should participate actively and directly in making important local decisions in Germany, Switzerland, the Czech Republic, Italy, Croatia, Norway, Poland, Austria, Greece, the United Kingdom, France, Israel and Spain. This is a logical perception of local councillors when considering that Poland, Greece, Spain, Croatia, Italy and the Czech Republic have faced the lowest level of trust in politicians among all analysed countries. 92 percent of local councillors in Croatian cities find that citizens' active participation is important for local democracy, which is a consequence of democratic reforms in Croatia.

Between 48 percent of local councillors in Israel and 88 percent of local councillors in Sweden find that local elections should be the most important factor in determining municipal policies. On average, 69 percent of local councillors in all analysed countries find it important. This share is the lowest in the Anglo group (49 percent) and largest in Northern and Middle European countries (71 percent).

About 82 percent of local councillors from Central Eastern European countries consider that it is important that local politicians try to achieve consensus and shared values among citizens.

The perception of local councillors that apart from voting citizens should not be given the opportunity to influence local government policies receives the lowest mean score. In the Northern and Middle European group (Germany, Switzerland, the Netherlands, Sweden, Norway and Austria) the mean score is at the lowest level (1.16). Voting is still an important mechanism for decision-making in the analysed countries. A proof of this is the high turnout in local elections. Thus, for example, in Norway the turnout in the 2015 local elections was 60.2 percent or 62 percent among women and 57 percent among men (Statistics Norway, 2017).

A large number of local councillors think that voting should not be the only type of citizen participation in local economic policy in all analysed countries. Around 15 percent of all respondents believe that it is of great or utmost importance that citizens influence local policy only though voting. The largest number of local councillors with such an opinion is in Greece (44 percent) and Poland (39 percent). This is, on one hand, an unexpected result knowing that these two countries have been faced with a low trust in politics and medium high fiscal autonomy. Local councillors' attitudes indicate that they find that citizens had an opportunity to vote for preferred local politicians' programmes at local elections and that they could be relatively fiscally autonomous for the adoption of measures concerning local economic policy. 
DRUŠ. ISTRAŽ. ZAGREB GOD. 27 (2018), BR. 1 STR. $155-175$

JURLINA ALIBEGOVIĆ, D. SLIJEPČEVIĆ, S.: ATTITUDES TOWARDS...

(1) TABLE 6

Local councillors' opinion regarding the process of further decentralisation and involvement of citizens in public decision-making
In the next part of the research we present results of a survey on the opinion of local councillors regarding the further process of decentralisation and whether a higher involvement of citizens in public decision-making is necessary (Table 6). A higher level of decentralisation should imply that citizens' influence on local development and the efficiency in public service delivery could be higher than in the countries with a lower level of decentralisation. In the literature, there are only a few studies that indicated the level of public support for increasing the responsibilities of local government. Baker, Van De Walle \& Skelcher (2011) presented research results on citizens' support for increasing the responsibilities of local government in European countries indicating huge differences between countries. For example, citizens in the Czech Republic give the highest support to the idea of granting more power to local government. On the other side are citizens in Hungary and the Netherlands because they give little support to such an idea. In Central and Eastern European countries, citizens are in between and there are a great number of supporters for increasing the responsibilities of local authorities.

\begin{tabular}{|c|c|c|c|c|c|c|}
\hline Statement & $\begin{array}{l}\text { Franco } \\
M\end{array}$ & $\begin{array}{l}\text { Anglo, } \\
M\end{array}$ & $\begin{array}{l}\text { Northern } \\
\text { and Middle } \\
\text { Europe } \\
M\end{array}$ & $\begin{array}{l}\text { Central } \\
\text { Eastern } \\
\text { Europe } \\
M\end{array}$ & $d f$ & $F$ \\
\hline $\begin{array}{l}\text { Political parties are the most suitable } \\
\text { arena for citizens' participation }\end{array}$ & 3.52 & 3.79 & 3.93 & 3.23 & 3 & 253.537 \\
\hline $\begin{array}{l}\text { Decentralisation of local government } \\
\text { is necessary to involve citizens } \\
\text { in public affairs }\end{array}$ & 3.72 & 3.99 & 3.37 & 3.91 & 3 & 222.567 \\
\hline
\end{tabular}

Note: All is significant at the $p=0.000$ level. Statements are analysed using a 5-point Likert scale, where the scores are balanced on the both sides of the neutral opinion.

The results of our research indicate that a large number of local councillors consider that decentralisation contributes to local democracy and that it is necessary to involve citizens in public affairs. The largest share of respondents in Croatia support this idea. Croatian experts agree that further decentralisation of public administration is necessary, but it must be a process that will involve experts and should never be just a hasty political decision (Jurlina Alibegović, Slijepčević, \& Kordej-De Villa, 2013; Jurlina Alibegović \& Slijepčević, 2012; Koprić, 2009; Kregar et al., 2011). On average, Anglo and Central Eastern European countries find decentralisation more important for citizens' involvement in decision-making than Franco 
DRUŠ. ISTRAŽ. ZAGREB GOD. 27 (2018), BR. 1, STR. 155-175

JURLINA ALIBEGOVIĆ, D. SLIJEPČEVIĆ, S.: ATTITUDES TOWARDS.. and Northern and Middle European countries. The main results of our analysis are comparable to the conclusions of research conducted by Baker, Van De Walle, \& Skelcher (2011). In the United Kingdom there is a strong effort for further decentralisation known as the decade for a new deal for local governance. Associated with the EU referendum results and "Brexit" and its implications on the economy, it is expected that the government and politics plan new forces for driving growth, with the strong support of cities and regions. Those are probably the reasons why a large number of local councillors in the United Kingdom consider decentralisation important for citizens' involvement in the public affairs. The United Kingdom belongs to the group of countries with a significant role of sub-national government in sharing responsibilities for public services, as well as to countries with a medium low fiscal autonomy of sub-national governments. Those are the reasons why there is a growing voice for the need for further decentralisation and devolution in the United Kingdom which is being driven by the needs of the largest cities that are drivers of development in the country. Contrary to that, France and Norway are in the group of countries where the distribution of powers and responsibilities of local economic development are in the hands of sub-national governments and, furthermore, the level of fiscal autonomy of local governments is already high. Based on this evidence, we are not surprised with the perception of local councillors in Franco and Northern and Middle European countries regarding the importance of the decentralisation of citizens' involvement in decision-making.

According to the literature, countries also differ in the mechanisms of citizens' participation (Council of Europe, 2011a). Thus, in the next part we test if there is a significant difference in local councillors' views towards the most effective mechanism of public participation in decision-making.

Our results show that there are significant differences at $p<0.01$ level between groups of countries regarding local councillors' opinions on all analysed mechanisms of public participation in the decision-making process (Table 7). On average, voting is considered to be the most effective mechanism for public participation in all groups of countries, while citizens' juries are the least effective mechanism for participation. Apart from voting, the biggest support is given to public meetings in the Franco group, while this support is somewhat lower in centralised-liberal and post-transitional countries. According to Sweeting \& Copus (2013), public meetings have the highest support in the countries analysed. 


\begin{tabular}{|c|c|c|c|c|c|c|}
\hline $\begin{array}{l}\text { (1) TABLE } 7 \\
\text { Mechanism of public } \\
\text { participation, mean } \\
\text { scores }\end{array}$ & $\begin{array}{l}\text { Franco } \\
M\end{array}$ & $\begin{array}{l}\text { Anglo, } \\
M\end{array}$ & $\begin{array}{l}\text { Northern } \\
\text { and Middle } \\
\text { Europe } \\
M\end{array}$ & $\begin{array}{l}\text { Central } \\
\text { Eastern } \\
\text { Europe } \\
M\end{array}$ & $d f$ & $F$ \\
\hline Voting & 3.28 & 3.29 & 3.10 & 3.24 & 3 & 35.333 \\
\hline Party meetings & 2.24 & 1.98 & 2.28 & 2.00 & 3 & 42.623 \\
\hline Petitions & 2.38 & 2.16 & 2.24 & 2.32 & 3 & 18.470 \\
\hline Citizens' juries & 2.09 & 1.84 & 1.98 & 1.86 & 3 & 9.128 \\
\hline Public meetings & 2.83 & 2.50 & 2.52 & 2.70 & 3 & 92.155 \\
\hline Satisfaction surveys & 2.69 & 2.42 & 2.25 & 2.50 & 3 & 151.492 \\
\hline Complaints' schemes & 2.49 & 2.33 & 2.11 & 2.38 & 3 & 122.837 \\
\hline Referenda & 2.45 & 2.06 & 2.78 & 2.48 & 3 & 133.448 \\
\hline Consultation with local agencies & 2.31 & 2.30 & 2.29 & 2.38 & 3 & 2.956 \\
\hline Consultation with community groups & 2.67 & 2.71 & 2.53 & 2.61 & 3 & 21.047 \\
\hline
\end{tabular}

Note: All is significant at the $p=0.000$ level.

\section{CONCLUSION}

Although there is not much evidence, research conducted in other fields has recognised the important role of citizen participation in decision-making. Citizen participation influences the quality of service, strengthens the skills to use the service and ensures that the public needs are met. Research conducted on local management and development has provided evidence that local autonomy gives opportunities for citizens and local representatives to interact. In this interaction, the most important question is not how many citizens have participated in any activity at local level, but whether the citizens' opinion is represented. Efficiency in local public service delivery is not possible if citizens do not know what to expect from local self-government and if local authorities, providing the service, do not know what citizens expect from the received public services.

Comparative analysis showed that although most local councillors in 16 analysed countries have positive attitudes towards public participation, differences between countries could be observed. Most of them agree that residents should have the opportunity to make their views known before important local decisions are made by elected representatives. However, a high number of them consider that elected representatives should conduct policy according to their own opinion and independently of the current views of local people. This shows that the level of participatory democracy could be significantly improved. According to local councillors' opinion, decentralisation reforms should positively contribute to citizen participation in decision-making by bringing service provision 
DRUŠ. ISTRAŽ. ZAGREB GOD. 27 (2018), BR. 1, STR. $155-175$

JURLINA ALIBEGOVIĆ, D. SLIJEPČEVIĆ, S.: ATTITUDES TOWARDS. closer to the citizens. Local self-government units have a large influence on economic development and thus local units should raise the importance of public participation in the decision-making process at the local level (Howard, Lipsky, \& Marshall, 1994; Glaser, Yeager, \& Parker, 2006).

The research showed significant differences in the perception of local councillors regarding the importance of citizen participation in decision-making at the local level, but also some common characteristics. Regardless of which group of countries belong to the expanded Hesse-Sharpe (1991) typology, the analysis showed that citizen participation is an important factor of local democracy and includes decision-making by citizens in public service delivery. In all the groups of analysed countries voting is the most preferable mode of public participation and citizens' juries are the least desirable mode for citizens' involvement.

A large number of countries conducted reforms with the aim to increase local economic development by increasing responsibilities of locally elected representatives along with an increase in efficiency in the provision of local public services. Decentralisation empowers local representatives and increases their role in local governance. This also increases the importance of higher influence of citizens and civil society organisations on policy-making before the decisions are taken and represent an important pillar of democracy. The majority of local councillors find that further decentralisation is necessary in order to increase public participation in the decision-making process. The precondition for efficient local public service delivery is that citizens know what to expect from local self-government and that local authorities, who provide the service, know what citizens expect from the public services received.

\section{ACKNOWLEDGEMENTS}

This research was conducted based on the Municipal Assemblies in European Local Governance (MAELG) project. We are grateful to the members of all sixteen national teams which were included, with us, in collecting the data. The details about the project can be found on: http://www.eizg.hr/en-US/MunicipalAssemblies-in-Croatian-Local-Governments-351.aspx or in Egner et al. (2013).

\section{REFERENCES}

Abelson, J., Forest, P-G., Eyles, J., Smith, P., Martin, E., \& Gauvin, F-P. (2003). Deliberations about deliberative methods: Issues in the design and evaluation of public participation processes. Social Sciences $\mathcal{E}$ Medicine, 57(2), 239-251. https://doi.org/10.1016/S0277-9536(02)00343-X

Baker, K., Van De Walle, S., \& Skelcher, C. (2011). Citizen support for increasing the responsibilities of local government in European coun- 
DRUŠ. ISTRAŽ. ZAGREB GOD. 27 (2018), BR. 1 STR. $155-175$

JURLINA ALIBEGOVIĆ, D. SLIJEPČEVIĆ, S. ATTITUDES TOWARDS. tries: A comparative analysis. Lex Localis - Journal of Local Self-Government, 9(1), 1-21.

Bertrana, X., Egner, B., \& Heinelt, H. (Eds.) (2016). Policy making at the second tier of local government in Europe. What is happening in provinces, counties, departments and landkreise in the on-going re-scaling of statehood? London and New York: Routledge, Taylor \& Francis Group.

Box, R. C. (1998). Citizen governance: Leading American communities into the 21st century. Thousand Oaks, CA: Sage Publications. https://doi. org/10.4135/9781483328249

Callahan, K. (2007). Citizen participation: Models and methods. International Journal of Public Administration, 30(11), 1179-1196. https://doi. org/10.1080/01900690701225366

Chi, C. S. F., Xu, J., \& Xue, L. (2014). Public participation in environmental impact assessment for public projects: A case of non-participation. Journal of Environmental Planning and Management, 57(9), 1422-1440. https://doi.org/10.1080/09640568.2013.810550

Council of Europe (2011a). Resolution 326, Citizen participation at local and regional level in Europe. Available at https://wcd.coe.int/ViewDoc. jsp?id $=1854777 \&$ Site $=$ Congress.

Council of Europe (2011b). Citizen participation at local and regional level in Europe. Available at https://wcd.coe.int/ViewDoc.jsp?id=1841 209\&Site $=$ Congress.

Day, D. (1997). Citizen participation in the planning process: An essentially contested concept? Journal of Planning Literature, 11(3), 421-434. https://doi.org/10.1177/088541229701100309

Ebdon, C. (2002). Beyond the public hearing: Citizen participation in the local government budget process. Journal of Public Budgeting, Accounting and Financial Management, 14(2), 273-294. https://doi.org/10. 1108/JPBAFM-14-02-2002-B006

Egner, B., Sweeting D., \& Klok, P.-J. (2013). Local councillors in Europe. Wiesbaden: Springer VS, Germany. https://doi.org/10.1007/978-3-65801857-3

European Institute for Public Participation (2009). Public participation in Europe: An international perspective. Bremen: European Institute for Public Participation.

Eyben, R., \& Ladbury, S. (2006). Building effective states: Taking a citizen's perspective. Brighton: Institute for Development Studies, Development Research Centre on Citizenship, Participation and Accountability.

Forrester, S., \& Sunar, I. (2011). Sudjelovanje građana i građanki u procesima donošenja odluka [Citizen participation in decision-making processes]. Sarajevo: Tehnička pomoć za organizacije civilnog društva - TACSO Regionalni ured. Available at http://tacso.civilnodrustvo-istra.hr/PDF/ Sudjelovanje $\% 20$ gradjana $\% 20 \mathrm{i} \% 20$ gradjanki $\% 20 \mathrm{u} \% 20$ procesima $\%$ 20donosenja\%20odluka.pdf

Gilbreath Holdar, G., \& Zakharchenko, O. (2002). Citizen participation handbook. Kyiv: iMedia Ltd.

Glaser, M. A., Yeager, S. J., \& Parker, L. E. (2006). Involving citizens in the decisions of government and community: Neighbourhood-based 
DRUŠ. ISTRAŽ. ZAGREB GOD. 27 (2018), BR. 1, STR. $155-175$

JURLINA ALIBEGOVIĆ, D. SLIJEPČEVIĆ, S.: ATTITUDES TOWARDS. vs. government-based citizen engagement. Public Administration Review. Summer, 177-217. Available at http://citeseerx.ist.psu.edu/viewdoc/ download?doi $=10 \cdot 1 \cdot 1.469 .3498 \&$ rep $=$ rep $1 \&$ type $=$ pdf

Hartay, E. (2011). Citizen participation, best practices in the Western Balkans and the European Union. Prishtinë: KCSF.

Heinelt, H. (2013). Councillors' notions of democracy, and their role perception and behaviour in the changing context of local democracy. Local Government Studies, 39(5), 640-660. https://doi.org/10.1080/ 03003930.2012.670746

Hesse, J. J., \& Sharpe, L. J. (1991). Local government in international perspective - Some comparative observations. In J. J. Hesse (Ed.), Local government and urban affairs in international perspective: Analysis of 20 western industrialised countries (pp. 603-621). Baden-Baden: Nomos Verlagsgeselschaft.

Howard, C., Lipsky, M., \& Marshall, D. R. (1994). Citizen participation in urban politics: Rise and routinization. In G. E. Peterson (Ed.), Big-city politics, governance, and fiscal constraints (pp. 153-199). Washington, D.C.: Urban Institute Press.

Irvin, R. A., \& Stansbury, J. (2004). Citizen participation in decision-making: Is it worth the effort? Public Administration Review, 64(1), 55-65. https://doi.org/10.1111/j.1540-6210.2004.00346.x

Ismeri Europa \& Applica (2010). Distribution of competences in relation to regional development policies in the member states of the European Union. Final report for DG REGIO. Brussels: European Commission. Jurlina Alibegović, D., Slijepčević, S., \& Kordej-De Villa, Ž. (2013). Can local governments in Croatia cope with more responsibilities. Lex Localis: Journal of Local Self-Government, 11(3), 471-497.

Jurlina Alibegović, D., \& Slijepčević, S. (2012). Decentralization in Croatia: Problems and possible solutions. EUGOV Working Paper, No. 33, 2012, pp. 35. Barcelona: The Institut Universitari d'Estudis Europeus - IUEE (University Institute of European Studies).

Kelly, J. M., \& Swindell, D. (2002). A multiple-indicator approach to municipal service evaluation: Correlating performance measurement and citizen satisfaction across jurisdictions. Public Administration Review, 62(5), 610-621. https://doi.org/10.1111/1540-6210.00241

Koprić, I. (2009). Decentralizacija i dobro upravljanje gradovima [Decentralisation and good city governance]. Hrvatska javna uprava, 9(1), 69-78.

Kregar, J., Đulabić, V., Gardašević, Đ., Musa, A., Ravlić, S., \& Rogić Lugarić, T. (2011). Decentralizacija [Decentralisation]. Zagreb: Centar za demokraciju i pravo Miko Tripalo.

LogoLink. Learning Initiative on Citizen Participation and Local Governance (2004). Resources, Citizen Engagements and Democratic Local Governance (ReCitE). A Topic Guide Prepared for the International Workshop on Resources, Citizen Engagements and Democratic Local Governance (ReCitE). Porto Alegre, Brazil, 5-9 December 2004. Available at http://portals.wi.wur.nl/files/docs/msp/Resources_Citizen_En gagement_and_Local_Governance.pdf

Lopižić, I. (2015). Javna uprava i politički sustav u Francuskoj: središnja uloga države, uprave i prava [Public administration and the 
DRUŠ. ISTRAŽ. ZAGREB GOD. 27 (2018), BR. 1 STR. 155-175

JURLINA ALIBEGOVIĆ, D. SLIJEPČEVIĆ, S. ATTITUDES TOWARDS... political system in France: The central role of the state, administration and law]. Croatian and Comparative Public Administration, 15(1), 103-140.

Lowndes, V., Pratchett, L., \& Stoker, G. (2001). Trends in public participation: Part 1 - Local government perspectives. Public Administration, 79(1), 205-222. https://doi.org/10.1111/1467-9299.00253

Michels A., \& De Graaf, L. (2010). Examining citizen participation: Local participatory policy making and democracy. Local Government Studies, 36(4), 477-491. https://doi.org/10.1080/03003930.2010.494101

Organisation for Economic Co-operation and Development (2001). Citizens as partners: OECD handbook on information, consultation and public participation in policy-making. Paris: Organisation for Economic Co-operation and Development. Available at http://www.internatio nalbudget.org/wp-content/uploads/Citizens-as-Partners-OECDHandbook.pdf

Pavić-Rogošić, L. (2012). Rezultati istraživanja: Imaju li građani što za reći? Sudjelovanje organizacija civilnog društva u donošenju odluka na lokalnoj razini [Research results: Do citizens have something to say? Participation of civil society organisations in decision-making at the local level]. Zagreb: ODRAZ.

Petts, J. (2001). Evaluating the effectiveness of deliberative processes. Journal of Environmental Planning and Management, 44(2), 207-226. https://doi.org/10.1080/09640560120033713

Ploštajner, Z., Nizak, P., Klepčić, N., Miljević, D., Cernicova, M., \& Zvrko, I. (2001). Citizens' participation in local self-government experiences of South-East European countries. Zagreb: Friedrich Ebert Stiftung Zagreb Office. Available at http://www.fes.hr/E-books/pdf/Citizens\% 20Partipation\%20in\%20Local\%20Self-Government/09.pdf

Quick, K. S., \& Bryson, J. M. (2016). Public participation. In C. Ansell \& J. Torfing (Eds.), Handbook in theories of governance (pp. 158-169). Cheltenham and Northampton MA: Edward Elgar Press. https://doi. org/10.4337/9781782548508.00022

Razin, E., \& Hazan, A. (2014). Attitudes of European local councillors towards local governance reforms: A north-south divide? Local Government Studies, 40(2), 264-291. https://doi.org/10.1080/03003930.2012.747957

Renn, O., Webler, T., Rakel, H., Dienel, P., \& Johnson, B. (1993). Public participation in decision making: A three-step procedure. Policy Sciences, 26(3), 189-214. https://doi.org/10.1007/BF00999716

Roberts, N. (2004). Public deliberation in an age of direct citizen participation. The American Review of Public Administration, 34(4), 315-353. https://doi.org/10.1177/0275074004269288

Robinson, M. (2007). Does decentralization improve equity and efficiency in public service delivery provision? IDS Bulletin, 38(1), 7-17. https://doi.org/10.1111/j.1759-5436.2007.tb00333.x

Rosenberg, S. R. (Ed.) (2007). Deliberation, participation and democracy. Can the people govern? New York: Palgrave Macmillan. https://doi.org/ $10.1057 / 9780230591080$

Skelcher, C. (1992). Improving the quality of local public services. The Service Industries Journal, 12(4), 463-477. https://doi.org/10.1080/02642 069200000059 
DRUŠ. ISTRAŽ. ZAGREB GOD. 27 (2018), BR. 1, STR. $155-175$

JURLINA ALIBEGOVIĆ, D. SLIJEPČEVIĆ, S.: ATTITUDES TOWARDS.
Soos, G. (2003, March 28 - April 2). Local participation and participatory institutions in Hungary. Paper presented at workshop 22: "Bringing the citizens back in - Participatory democracy and political participation", the Joint Sessions of Workshops of the European Consortium for Political Research, Edinburgh, United Kingdom.

Statistics Norway (2017). Available at https://www.ssb.no/en/valg/sta tistikker/kommvalg

Sweeting, D., \& Copus, C. (2013). Councillors, participation, and local democracy. In B. Egner, D. Sweeting, \& P.-J. Klok (Eds.), Local councillors in Europe (pp. 121-137). Wiesbaden: Springer VS, Germany. https://doi.org/10.1007/978-3-658-01857-3_7

Tanaka, S. (2007). Engaging the public in national budgeting: A non-governmental perspective. OECD Journal of Budgeting, 7(2), 139-177. https://doi.org/10.1787/budget-v7-art12-en

Thomas, J. C. (1995). Public participation in public decisions. San Francisco: Jossey-Bass.

UK Open Government Network (2017). Available at http://www.open government.org.uk/

Wamsley, G. L., \& Wolf, J. F. (Eds.) (1996). Refunding democratic public administration. Thousand Oaks, CA: Sage.

Wilson, D. (1999). Exploring the limits of public participation in local government. Parliamentary Affairs, 52(2), 246-259. https://doi.org/10.1093/ $\mathrm{pa} / 52.2 .246$

World Economic Forum (2015). The global competitiveness report 20142015. Geneva: World Economic Forum.

\section{Stavovi o sudjelovanju građana $u$ procesu donošenja odluka na lokalnoi razini: komparativna analiza}

\section{Dubravka JURLINA ALIBEGOVIĆ, Sunčana SLIJEPČEVIĆ} Ekonomski institut, Zagreb

Uključivanje građana u proces donošenja odluka predstavlja važan stup demokracije. Znanstvena literatura prepoznaje promjenu iz "vladavine" u "upravljanje", što uključuje i veće uključivanje različitih dionika u proces odlučivanja te $u$ proces provedbe javnih politika. Sudjelovanje građana u procesu pružanja javnih usluga može dovesti do boljih javnih usluga, koje su u skladu s potrebama građana, boljih odluka, kvalitetnije i učinkovitije suradnje u korištenju javnog novca za osiguranje javne usluge. U ovom se istraživanju empirijski testiraju stajališta o uključivanju građana u proces donošenja odluka na lokalnoj razini. $U$ istraživanju se ispituju stavovi lokalnih vijećnika iz 16 država podijeljenih prema proširenoi Hesse-Sharpe (1991) klasifikaciii. Analiza se temelji na rezultatima anketnog ispitivanja provedenog među lokalnim vijećnicima u gradovima. $U$ istraživanju se iz 
DRUŠ. ISTRAŽ. ZAGREB GOD. 27 (2018), BR. 1 STR. 155-175

JURLINA ALIBEGOVIĆ, D. SLIJEPČEVIĆ, S

ATTITUDES TOWARDS.. komparativne perspektive analiziraju različiti načini sudjelovanja građana u procesu donošenja odluka. Istraživanje je pokazalo da je glasanje preferirani mehanizam javnog sudjelovanja u svim grupama država, dok je sudjelovanje građana u svojstvu povremenih sudaca laika (porotnika) najmanje preferirani mehanizam sudjelovanja građana. Ovaj rad doprinosi popunjavanju nedovoljnog broja istraživanja o ulozi i važnosti sudjelovanja građana u procesu donošenja odluka u Europi.

Ključne riječi: sudjelovanje građana, lokalni vijećnici, lokalne javne usluge, lokalni razvoi

\section{(c) (1) $\Theta \Theta$}

Međunarodna licenca / International License:

Creative Commons Attribution-NonCommercial-NoDerivatives 4.0. 